\title{
INTEGRATED SAFETY IMPLICATIONS FOR PROJECT MANAGEMENT
}

Safety insurance provisions in the broadest sense of the term belong among major tasks and challenges for a company management as well as any municipality administration. In the framework of the decision making process, the manager or administrator takes into account a lot of factors, among which - apart from safety risks - financial possibilities of the company or municipality are of major importance. The decisions made have a project character, and managers and administrators can take advantage of project management tools to be able to assess viability of the decisions suggested, as well as their implementation. This paper concentrates on the prior-to-investment process of the project management, and the paper's focal point is in suggesting a method for technical and economic (cost efficiency) assessment of safety projects.

Keywords: Integral safety, project management, feasibility study, risk

\section{Introduction}

The modern industrial society human life implies not only lot of advantages but also many safety risks in the broadest sense of the term. The man and society are faced with many emergencies (natural disasters, industrial and traffic accidents, terrorist attacks, criminal acts, epidemics or pandemics. In the expert literature on the subject [1] but especially in day-to-day practice, there is a term of integral safety common, which addresses safety and risk issues in their complexity. Safety and risk provisions represent a must for human and social developments and, as such, ask for constant attention of executive institutions and politicians.

The issue of safety can be watched from two vantage points. Either it is about prevention, of which the implementation reduces the impending risk, or it is about a remedying action that should cope with situations of running emergency. After gaining mastery over the situation of the running emergency, the action of renewal and rehabilitation follows.

The preventive and remedying actions can be regarded as projects that are implemented by application of project management tools and methods, which ask for decisions to be taken and investment demands met by related authorities (managers, politicians). A critical judgement must be passed on the investment demands, especially in the current situation of tight budget control and budgetary restrictive measures.
The project management involves a wide variety of specific issues, and this paper has concentrated on key issues of project technical and economic assessments - feasibility study.

Project technical and cost efficiency assessments usually concern profitability of a project. It is obvious that primary stages of such project feasibility studies and their documentation are oriented by these objectives. The expert literature, for example Fotr and Soucek [2]; Valach [3]; Nemec [4]; or Sieber [5], on the subject takes heed of the recommendations, UNIDO ${ }^{1)}$ [6]. The safety projects do not directly imply profit and applications of standard methods can be difficult or even misleading. For that reason, it is necessary that the method is modified to be able to conform to conditions of safety project assessment and management.

This paper has focused on such modification and suggests a method that would satisfy the needs of safety project assessments. The publication of this modification could possibly start a discussion on the matter, which might improve our suggestions.

\section{Theoretical starting points}

As this paper has focused on feasibility studies, we shall discuss the subject in detail. A feasibility study objectives are to elaborate details of technological, economic, financial, and managerial aspects of a project. Such study should provide for all information that is

\footnotetext{
* Michal Vanek ${ }^{1}$, Yveta Tomaskova ${ }^{2}$, Michal Senovsky ${ }^{3}$, Lucie Krcmarska ${ }^{4}$

${ }^{1}$ Institute of Economics and Control Systems, Faculty of Mining and Geology, VSB-Technical University of Ostrava, Czech Republic

${ }^{2}$ Institute of Combined Studies in Most, Faculty of Mining and Geology, VSB-Technical University of Ostrava Czech Republic

${ }^{3}$ Department of Civil Protection, Faculty of Safety Engineering, VSB-Technical University of Ostrava, Czech Republic

${ }^{4}$ Institute of Economics and Control Systems, Faculty of Mining and Geology, VSB-Technical University of Ostrava, Czech Republic, E-mail: michal.senovsky@vsb.cz

1) UNIDO - United Nation Industrial Development Industry Organization
} 
essential for general evaluation of a project, which results in its admission or rejection [2]. A feasibility study structure is not precisely defined. It is only respectful of the recommendations, UNIDO. Some experts, for example Fotr and Soucek [2]; Valach [3]; Nemec [4]; or Sieber [5], differentiate only the number and sequence of individual items, but they fully agree on the overall content of the study, and all of them complete it by an analysis of the project risks. As it has been already mentioned above, this method serves the needs of developing entrepreneurial (industrial) investment projects. In practice, it is also applied to developing of public utility project, at which point, it is completed by a cost benefit analysis, CBA, [5].

An application of feasibility study standard structures for safety project developments is rather difficult regarding specific features of the safety projects. An example can be served by Item 3, Market Analysis and Marketing Strategy, which is irrelevant for safety project management and development. As such, the common structure and contents of feasibility studies need to be adapted to specific features of safety projects.

A logical and key starting point for integral safety project developments is provided by a risk analysis, which is usually specified as a process of identifying threats, their stochastic nature and impact, i.e. it is about defining risks and their severity [7].

Before making clear what is the risk analysis itself, it might be useful to clarify the meaning of the word, risk. Just to quote Smejkal: 'The term, risk, is promiscuously used to express both the meaning of probability occurrence of emergency, and the meaning of emergency impact and consequence' [7]. We think that the ambiguity can be avoided if we clearly distinguish between a threat and its stochastic nature (risk).

The safety projects ask for correlating of threats or risks with two principal issues. The first issue is represented by the safety per se, the second regards risks of the project itself. The first issue concentrates on description of integral risks, the impact of which cannot be tolerated [1]. The second issue regards factors that can jeopardize implementation of projects and their functionality. For example, these can be economic, legislative, political, technical/technological, and safety factors. As both issues imply different information and conclusions, project compilers must especially focus on two items, which are specified in the following chapter.

The risk analysis can be conducted by applying many specific methods that are described by expert literature (for example, [8] or [7]). The methods can be generally divided into two basic groups: non-systematic methods (for example, What-If, checklist analysis), and systematic methods (for example, cause and effect analysis, emergency and operability study). Each of the methods has its specificity with applicability implications [8].

The sense and objective of project technical and economic assessments is to provide for a qualified compilation of data at disposal of investment and financial decisions, of which project financial flows are of major importance [2].

\section{Suggesting a method of evaluating integral safety projects}

If we consider safety projects, feasibility studies are initiated by studies identifying threats and assets. The objective of such study, as its name implies, is to identify threats that have impact on assets. The study is conducted in the same spirit as an opportunity study, i.e. not in any greater detail. Once the threats have been identified and approximated, the next step of a technical and economic study can be worked out. This study should not hamper taking of qualified decisions concerning project implementations or solving problems of related safety. If it is a case of a major project, the feasibility study can be preceded by a preliminary technical and economic study, which differs from a feasibility study as regards only information details and completeness of analyses.

\section{Suggesting structure and contents of individual items of safety project feasibility study}

\subsection{Output summary}

The output summary sums up overall investment project characteristics regarding technical, economic, financial, and social issues of the project. It sets forth all essential feasibility study conclusions inclusive values of major parameters, results of marketing analysis, project investment recovery statement, and risk analysis.

\subsection{Basic information on project investor}

The majority of safety projects oriented by emergency prevention choose such protective measures that best reflect the investor's specific situation. That is why this item gives basic information on the investor, which can be a private or state enterprise, institution or municipality. The information comprises:

(i) Name (firm, institution, municipality); (ii) Statutory representative; (iii) Headquarters; (iv) Kind of entrepreneurial activity, company basic characteristics (organization, institution); (v) Company financial analysis - basic parameters (liquidity, indebtedness, profitability, assets or municipality budget, as the case might be); (vi) History and description of recent emergency preventive measures, and who will own or operate the project implemented.

\subsection{Safety risk analysis and risk reduction strategy}

The starting input for this feasibility study item is the already compiled list of threats, which substitutes an opportunity study. This item should analyse all risks that the investor's production facilities are running, and establish risks' stochastic characteristics:

1. Assessment of assets - It identifies values that are subject of protection.

2. Safety risk assessment - It is necessary to distinguish between external threats (natural disaster, human factor failure or com- 
bination of both), and internal threats (threats implied in a specific situation of running the enterprise (item, 11, deals with them in detail).

3. Risk significance rating - It is oriented by an expert evaluation referring to vulnerability of specific assets to particular threats.

4. Safety risk specification - A particular risk analysis method takes into account a specific environment, in which the emergency might occur. A statistic alternative provides for spread calculations, standard deviation, and coefficient of variation. If a greater number of threats is an option, the safety risk determination can take advantage of future risk scenarios or probability tree diagrams. The outcome probability of particular scenarios builds upon statistical histories or expert opinion figures. If the latter is the case, it can take advantage of the relative value method when a limited number of risks is the option. If the risk is extremely high or infinite, the quantile methods can be successfully applied ${ }^{2}$. The item, 3 , should also provide for a risk reduction strategy implying specific focus points of the integral safety project.

\subsection{Project basic idea and its objective}

This item gives a name, heart of the project matter, project necessity substantiation from technical, economic, or legislative points of view, inclusive specifications of limiting or even eliminating risks. Also project localization details are specified, as well as basic technical parameters.

\subsection{Project technical and technological aspects - Variants of realization}

The fifth item provides for various options of implementing the safety project. Each option informs on particular technical, technological and other related aspects (for example real-estate demands) of its implementation. The information comprises specification of demands on material and energy needed for realization of the project, which serves for calculating of investment costs that are detailed by the budgetary item, 10. Each option of the project realization should specify its life expectancy, taking into account current legislative background, availability of technologies, equipment, material, and energy resources.

\subsection{Material and energy intensity - Resource-based view perspective}

Material and energy intensity of each implementation option is detailed here. It states what kind and what amount of material and energy will be needed per annum for running of the individual option realized. Again, future material and energy availability must be taken into account, as well as other limiting factors like for example demands on environmental protection. Such details enable calculation of annual running costs of the project implemented.

\subsection{Contractor analysis - Supplier-based view perspective}

The information and data provided by items, 5 and 6 , serve the purpose of related market research as regards possible contractors and suppliers - competition intensity and advantages, market prices, delivery conditions and deadlines, all of which should be supported by reliable references. When all necessary data have been compiled, alternatives are assessed and specific contractors and suppliers chosen. The multi-criteria analysis can be applied to the contractor evaluation with the biggest advantage, as a single criterion analysis cannot identify all relevant factors of assessing contractors objectively.

At the same time, it is necessary to observe all related legislative measures and regulations, especially the Law on Public Open Tenders; CZ, No. 137/2006 Col.

\subsection{Project location demands and environmental impact}

It clearly specifies the project location and its space demands inclusive specifications of potential environmental impact. A map is attached to this feasibility study item.

\subsection{Organisation, management and demand on human resources}

If the realization of the safety project asks for organizational changes, creation of new job positions or restructuring of the existing managerial structure, the changes should be clearly specified, as regards responsibilities, competencies, and qualifications of the individual positions. In an annual perspective, it is also necessary to specify all personal costs.

\subsection{Implementation schedule and budget}

All interrelated activities of the safety project realization should be detailed inclusive their time schedule, in which all documentation is finished, contracts concluded, facilities built, and the project put in operation. All documentation should observe the current legislative provisions. If any facilities are built, the documentation also comprises a zoning and planning decision, building licence, and final building project.

The implementation plan also includes a budget needed for the project realization, and gives names of persons responsible for implementing of specific activities.

\footnotetext{
${ }^{2)}$ For example, methods of subjective probability assessments are described by 'Managerial Decision Making' by Fotr and Dedina [9].
} 
The application of network charts, critical path method or other similar method or procedure is to advantage of the implementation plan and budget developments.

A budget is integral to the implementation planning. It summarizes and details all investment costs (capital expenditure) of the safety project, and provides for a time schedule of the cost expenditure. The capital expenditure should not comprise costs that are not directly related to the realization of the project.

As the safety project implementation closely depends on availability of finances, this item should clearly specify financial resources (internal, external, public) of the project realization and their structure.

\subsection{Risk assessment}

The assessment of the safety project risk applies methods and procedures analogous to the risk analysis itself (item, 3), namely the safety project risk is assessed by:

1. Assessment of assets - Long term property that has been acquired to be able to compensate investor's assets if damaged,

2. Assessment of project risks - Technical/technological (technology reliability, obsolescence), financial (availability of financial resources, interest rate developments, exchange rate changes), economic (development and changes of material prices, energy, and manpower), legislative (related law amendments), and environmental (project environmental impact),

3. Risk significance rating - Conducted by an expert evaluation or vulnerability analysis,

4. Project risk specification - Conducted by direct projecting of statistical characteristics on a criterion selected (project cost efficiency) or advantage of scenarios, probability tree charts or subjective probability assessment can be taken.

\subsection{Financial analysis and investment evaluation}

It evaluates project cost efficiency, which influences the final decision about accepting or rejecting the project ${ }^{3)}$. The evaluation follows these steps:

I. Assessment of annual investment implied financial flows throughout the useful economic life of the investment:

The financial flow represents capital expenditure (investment total costs and schedule of spending have been already provided for by item, 10, budget) and annual revenue throughout the investment useful economic life, and liquidation. Financial flows are based on value increments and take into account taxation, as well as all indirect consequences of investment spending (for example floating capital increases or staff training costs). The taxes implied in investment spending are not considered, the project is assessed as independent of the mode of financing. Increases of contractor and supplier prices are not taken into account because of prediction difficulties, especially as regards long-term projects. Financial flows are assessed vis-à-vis project life expectancy or specific term of monitoring.

The assessment of the project revenue needs identification and evaluation of parameters that influence the income. It is about project costs and the income earned by the project annually, see Table 1 . Note that safety projects are usually not production projects, and a typically production income cannot be expected. The safety projects are usually realized to be able to avert expenditure implied in an emergency damage. The cost efficiency assessment takes this expenditure as income, of which the value is influenced by the emergency annual incidence, see item, 3 .

Annual costs and income

Table 1

\begin{tabular}{|c|c|}
\hline Annual costs - $\mathrm{C} 1$ & Annual income - R1 \\
\hline $\begin{array}{l}\text { Material and energy consumption } \\
\text { Services implied in operating the } \\
\text { investment } \\
\text { Wages and salaries, Social and } \\
\text { health insurance } \\
\text { Taxes and fees Depreciation on } \\
\text { the investment }\end{array}$ & $\begin{array}{l}\text { Income losses due to suspended } \\
\text { production caused by emergency } \\
\text { and related remedying action } \\
\text { Wages implied in suspended } \\
\text { production } \\
\text { Waste of material reserves } \\
\text { Costs of emergency remedying } \\
\text { action } \\
\text { Health risk implied costs } \\
\text { (emergency injury compensation) } \\
\text { Penalties implied in contract } \\
\text { default caused by emergency } \\
\text { Penalties implied in emergency } \\
\text { damage to environment }\end{array}$ \\
\hline
\end{tabular}

The issue of insurance and its cost efficiency assessment implications is of special importance. While a safety project realization represents an active attitude of the management to avert threat (risk), the insurance is an expression of a passive attitude to solving of the same problem. This fact should be taken into account by calculating the investment implied income. It is also necessary to reflect how insurance fees are related to the project implementation regarding options given by Table 2 :

\section{Choosing appropriate method for cost efficiency evaluation}

In view of the fact that real property structures of the project are often assets of long-term character or realization (building of a dam), it is appropriate to reflect the project time factor by applying a dynamic method of investment assessment. With regard to the character of the integrated safety projects, the current NPV (Net Present Value) would be the best alternative. A project can

\footnotetext{
${ }^{3)}$ If a project realization is to the benefit of other subjects, which can be the case of projects beneficial to public, the Item, Cost - Benefit Analysis (CBA), can establish individual subjects' project realization benefit or loss incurred.
} 
Insurance options

Table 2

\begin{tabular}{|c|l|l|}
\hline Option & Project influence on insurance & \multicolumn{1}{|c|}{ Influence on income } \\
\hline A & None & None \\
\hline B & $\begin{array}{l}\text { Insurance company agrees to } \\
\text { insurance rate reduction }\end{array}$ & $\begin{array}{l}\text { Insurance premium saving } \\
\text { included in income }\end{array}$ \\
\hline C & $\begin{array}{l}\text { Project non-realization implies } \\
\text { no policy }\end{array}$ & $\begin{array}{l}\text { Expenditure - annual } \\
\text { insurance costs paid } \\
\text { Revenue - damage incurred } \\
\text { payment of premium }\end{array}$ \\
\hline
\end{tabular}

Net investment income per annum (CZK) is simply assessed by aggregating annual operational profit decreased by tax and annual depreciation deductions.

be subject of admission if NPV $>0$; the higher the NPV-value the better.

An investment cost efficiency evaluation should also account for related risks. There are two ways how to do it - indirectly by a discount rate modification, at which point it is possible to take the integrated safety projects as analogous to new machinery investments, to which discount rates of $8-10 \%$ are commonly related. It can be also done indirectly by means of statistical characteristics, which might be in the case of safety project assessments a better option, where the optimum variant choice is based on assessing net present values and risks. If risks are directly reflected, the net value calculations employ risk-free discount rates that usually equal the investment yields on the state's general-obligation bonds ${ }^{4}$.

\section{Suggesting variants of project revenues per annum}

Annual income on the project can vary in individual years, which also depends on possible risk materialization, see item, 11. For that reason, net investment income should be calculated using the formula, (1):

- Emergency has been averted

- Emergency has materialized ${ }^{5}$.

The project annual costs are the same for both variants, but the annual yields differ. If emergency has been averted, the annual income follows from Tab. 1. If it has not been averted, the annual income will be reduced by all costs of necessary remedying action. Each individual variant reflects probability of emergency incidence, item, 3. At the same time, it is necessary to calculate income on zero variant (safety project has not been implemented), when annual income equals zero, and annual costs include all expenditures of emergency remedying actions, as predicted by item, 3 .

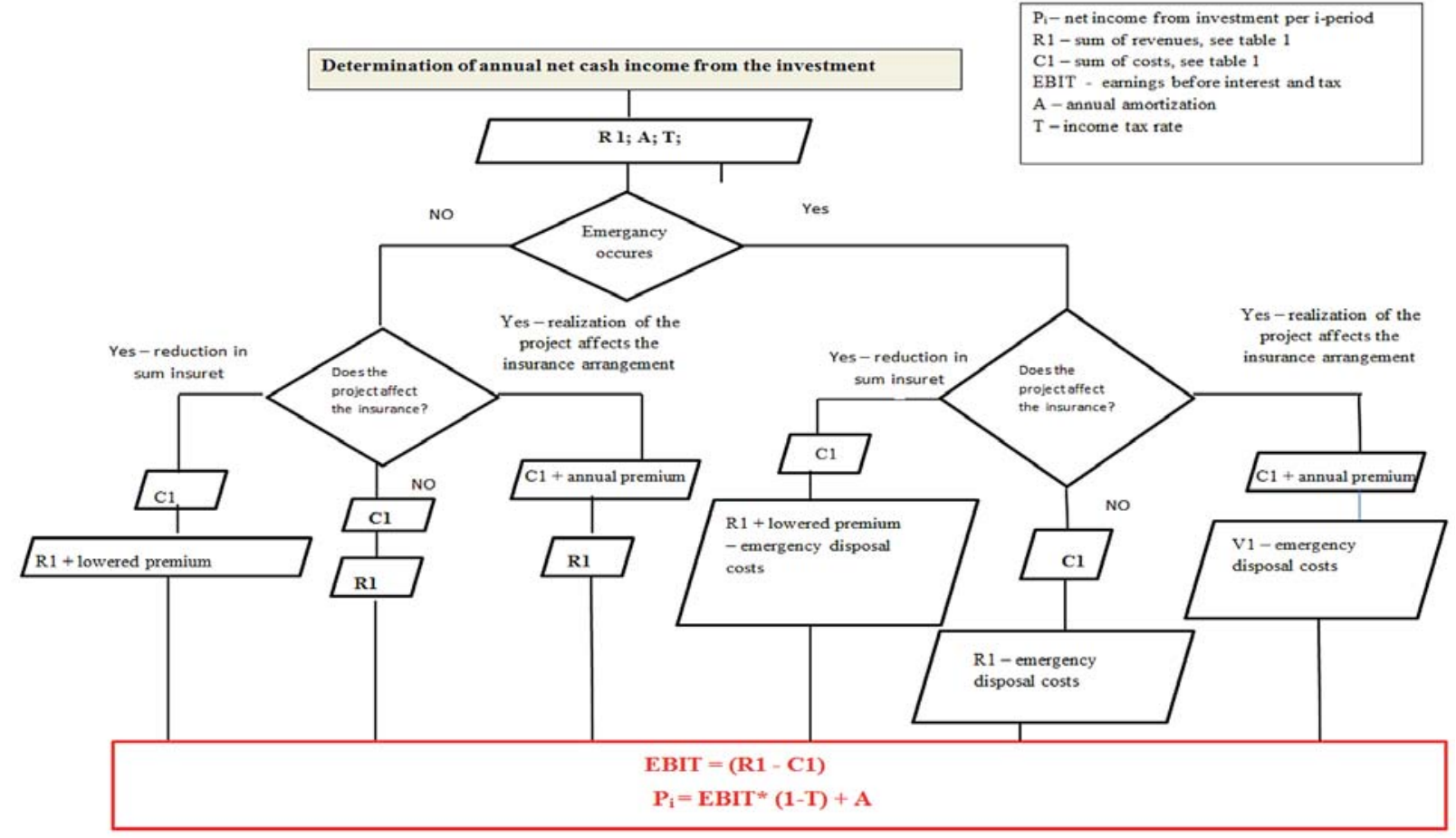

Fig. 1 Calculation procedure of the annual cash income from the investment

\footnotetext{
4) Yields on the state obligation bonds are $3-5 \%$ p. a.

${ }^{5)}$ Also another variant can be chosen: Emergency can be partly averted
} 


$$
P_{n}=E B I T *(1-T)+A
$$

$P_{n} \quad$ - cash income in the n-th year life EBIT - earnings before interest and tax

$$
A \text { - annual amortization }
$$

$T$ - income tax rate.

Calculation procedure of the annual cash income from the investment in particular ways taking into account issues of insurance is shown in Fig. 1.

\section{Calculating net present value of project}

Inasmuch as item, 3, has recommended developing project variants from the point of view of net annual income, the net present income calculation should use a modified formula NPV so that income variant probabilities are reflected; see formula, (2).

$$
N P V_{r}=\left(\sum_{n=1}^{N}\left(\sum_{j=1}^{J} P_{j} * p_{j}\right) \cdot \frac{1}{\left(1+i_{r}\right)^{n}}\right)-K
$$

$P_{j} \quad$-Variant's income anticipated [CZK]

$j \quad$ - Individual variants [CZK]

$J \quad$ - Number of variants

$i_{r} \quad$ - Risk-free discount rate, or discount rate

$n$ - Specific life expectancy year

$N \quad$ - Project life expectancy period [years]

$K$ - Capital income [CZK]

\section{Calculating variance of net present value}

The present net value variance, $\sigma_{N P V}^{2}$, equals the sum of discounted annual income variances, [9], see formula, (3); the greater its value the higher project risk.

$$
\sigma_{N P V}^{2}=\sum_{n=1}^{N} \frac{\sum_{j=1}^{J} P_{j}-\left(P_{j}^{*} p_{j}\right)}{\left(1+i_{r}\right)^{2 n}}
$$

If two projects of distinctly different average incomes are compared, it is necessary to compare their risks by means of a variance coefficient.

\section{Accept or reject project decision making}

If it is about deciding between two projects, $\mathrm{A}$ and $\mathrm{B}$; the project $\mathrm{A}$ is accepted if the following condition has been met:

$N P V_{A} \geq N P V_{B}$ and at the same time, $\sigma^{2} N P V_{A}<\sigma^{2} N P V_{B}$ or $N P V_{A}>N P V_{B}$ and at the same time, $\sigma^{2} N P V_{A} \leq \sigma^{2} N P V_{B}$, see Fig. 2

If variance coefficient is applied, as an alternative risk indicator, the project $\mathrm{A}$ is accepted under the condition:

$N P V_{A} \geq N P V_{B}$ and at the same time, $V_{A}<V_{B}$ or $N P V_{A}>N P V_{B}$ and at the same time, $V_{A} \leq V_{B}$.

A situation in which the project A would evidence a higher present value concurrent with higher risks, the existing theory cannot unequivocally solve the problem. Then, the outcome of the decision making process lies within individual managerial authority.

\section{Conclusion}

A successful project implementation depends on its right planning - defining, budgeting, scheduling [5]. The statement is even more valid as regards projects of integral safety. The very nature

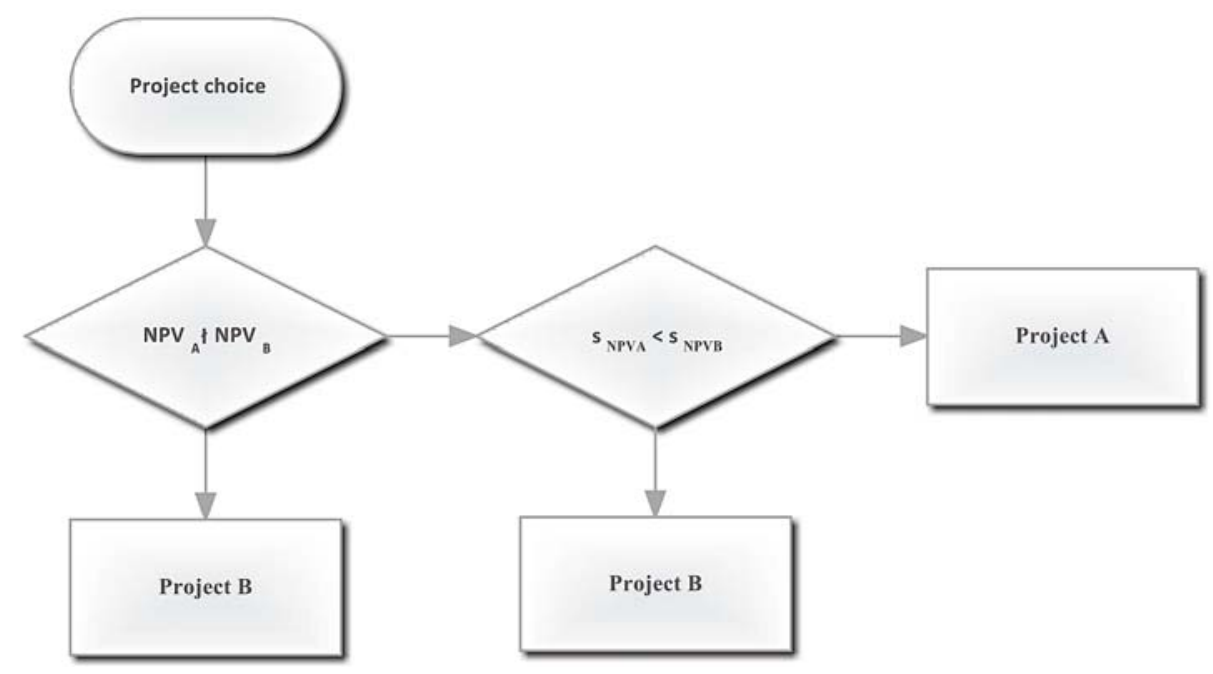

Fig. 2 Process of project choice 
of the safety projects does not allow direct application of methods common to standard commercial projects. The authors of this paper are positive that the accept or reject project decision making cannot be based only on safety issues. It is of equal importance, especially in the current situation of tight state, business, and municipality budget control and budgetary restrictive measures, to provide for sufficient cost efficiency assessment of projects. Presently, the authors could not identify any decision making tool or appropriate assessment method for the matter and have tried to provide for one. Our method of integral safety project evaluation is based on the method, UNIDO, common for cost efficiency assessment of investment projects. The method, UNIDO, has been modified to serve purposes of decision making processes concerning projects of integral safety. We are positive that managers of integral safety projects can use the method to increase quality and efficiency of their decision making. This article has been supported by grant of the Ministry of the Interior VF20112015018 Security of Population - Crisis Management.

\section{References}

[1] SENOVSKY, M., BALOG, K.: Integralni bezpecnost [Integral Safety] - $1^{\text {st }}$ edition, Ostrava : SPBI, 2009, p. 109. ISBN: 978-80-7385076-0.

[2] FOTR, J., SOUCEK, I.: Podnikatelsky zamer a investicni rozhodovani [Managerial Intent and Investment Decision Making] - $1^{\text {st }}$ edition, Praha : Grada Publishing, 2005, p. 356. ISBN 80-247-0939-2.

[3] VALACH, J.: Investicni rozhodovani a dlouhodobe financovani [Investment Decision Making and Long Term Financing]. $1^{\text {st }}$ edition, Praha : EKOPRESS, 2001, pp. 447. ISBN 80-86119-38-6.

[4] NEMEC, V.: Projektovy management [Project Management] - $1^{\text {st }}$ edition, Praha : Grada, 2002, p. 184. ISBN: 80-247-0392-0.

[5] SIEBER, P.: Financni a socioekonomicke hodnoceni projektu [Social and Cost Efficiency Project Assessment] [online]. 2008 [cit. 201010-25] WWW access: http://www.sieber-uchytil.cz/studie-proveditelnosti-feasibility.htmls.

[6] BEHRENS, W., HAWRANEK, P. M.: Manual for the Preparation of Industrial Feasibility Studies: Newly Revised and Expanded Edition. Vienna : Undo Publication, 1991, p. 386. Available on: WWW: <http://www.scribd.com/doc/37715708/Manual-for-the-Preparationof-Industrial-Feasibility-Studies>. ISBN 92-1-106269-1.

[7] SMEJKAL, V., RAIS, K.: Rizeni rizik ve firmach a jinych organicich [Risk Management in Companies and Other Organisations] - $2^{\text {nd }}$ extended edition, Praha : Grada Publishing, 2006, p. 296. ISBN 80-247-1667-4.

[8] BARTLOVA, I., BALOG, K.: Analyza nebezpeci a prevence prumyslovych havarii I [Risk Analysis and Prevention of Industrial Emergency, I] - $2^{\text {nd }}$ edition, Ostrava : SPBI, 2007, p. 172. ISBN: 978-80-7385-005-0.

[9] FOTR, J., DEDINA, J.: Manazerske rozhodovani [Managerial Decision Making] - $1^{\text {st }}$ edition, Praha : Ekopress, 1997, p. 207. ISBN 80-901991-7-8. 